\title{
Rahasia Inovasi Karyawan Wanita di Era Digital: Analisis Modal Psikologis dan Dukungan Kepemimpinan
}

\author{
Tias Pramono ${ }^{1^{*}}$ \\ Masduki Asbari ${ }^{2}$ \\ Heri Supriatna ${ }^{3}$ \\ Yunianto Agung Nugroho ${ }^{4}$ \\ Dewiana Novitasari ${ }^{5}$ \\ ${ }^{1}$ Sekolah Tinggi Ilmu Ekonomi Insan Pembangunan, Tangerang, Indonesia \\ Email: tipidai1@gmail.com \\ ${ }^{2}$ STMIK Insan Pembangunan, Tangerang, Indonesia \\ Email: kangmasduki.ssi@gmail.com \\ ${ }^{3}$ Universitas Mercu Buana, Jakarta, Indonesia \\ Email: heri.priatna74@gmail.com \\ ${ }^{2}$ STMIK Insan Pembangunan, Tangerang, Indonesia \\ Email: yunianto.nugroho76@gmail.com \\ ${ }^{5}$ Sekolah Tinggi Ilmu Ekonomi Insan Pembangunan, Tangerang, Indonesia \\ Email: dhewiediosa@yahoo.co.id
}

\begin{abstract}
Abstrak
Penelitian ini bertujuan untuk memastikan dan mengukuhkan berlakunya teori inovasi dan variabel antesedennyang yang relevan pada karyawan wanita di industri manufaktur yang masih relatif langka dalam dunia penelitian kontemporer. Oleh karena itu, penelitian ini berupaya mengukur pengaruh dukungan otonomi kepemimpinan dan modal psikologis terhadap perilaku inovatif individu pada karyawan wanita pada industri manufaktur di Tangerang. Dalam penelitian ini modal psikologis merupakan variabel mediasi. Data dikumpulkan dari 87 kuesioner yang dikembalikan dari sampel yang diambil secara random sampling. Data dianalisis menggunakan metode SEM dengan software SmartPLS 3.0. Hasil penelitian ini menunjukkan bahwa dukungan otonomi kepemimpinan berpengaruh signifikan terhadap modal psikologis, dukungan otonomi kepemimpinan dan modal psikologis berpengaruh signifikan terhadap perilaku inovatif individu, modal psikologis berpengaruh positif dan signifikan terhadap hubungan antara dukungan otonomi kepemimpinan dan perilaku inovatif individu. Modal psikologis berfungsi sebagai mediator parsial. Penelitian baru ini mengusulkan model pengelolaan perilaku inovatif individu pada karyawan wanita di industri manufaktur di Tangerang melalui pengembangan dukungan otonomi kepemimpinan dengan modal psikologis sebagai mediator. Penelitian ini dapat membuka jalan untuk meningkatkan kesiapan karyawan dalam menghadapi era revolusi industri 4.0 .
\end{abstract}

Kata kunci: Dukungan otonomi kepemimpinan; modal psikologis; perilaku inovatif individu; revolusi industry 4.0.

\section{PENDAHULUAN}

Inovasi adalah tujuan yang diinginkan untuk perusahaan modern yang sukses. Sebagian besar perusahaan dan organisasi menyadari perlunya bersikap proaktif dalam upaya "menemukan" atau menjadi inovatif. Tak terkecuali organisasi industry manufaktur. Meskipun terdapat banyak literatur tentang perilaku inovatif secara umum, namun masih sangat sedikit penelitian yang telah dilakukan pada unit analisis pegawai wanita di bidang industry manufaktur (Masduki Asbari, Pramono, Kotamena, et al., 2020; Sutardi et al., 2020; Yuwono, Novitasari, et al., 2020; Yuwono, Wiyono, et al., 2020). Sangat sedikit penelitian sebelumnya yang berfokus pada perilaku inovatif karyawan dalam kaitannya dengan aspek pemberdayaan karyawan dan produktivitas kerja (Chang \& Liu, 2008), pemberdayaan struktural dan psikologis (Knol \& Van Linge, 2009), motivasi dan stres yang dirasakan (Saleem et al., 2015). Justru rangkuman penelitian terdahulu mengisyaratkan dan mengasumsikan bahwa karyawan (individu) dalam organisasi adalah pendorong utama dan fundamental dari implementasi ide-ide baru. Karyawanlah adalah pihak pertama yang mempraktikkannya perilaku inovatif dalam pekerjaan mereka. Oleh karena itu, diperlukan lebih banyak penelitian tentang faktor-faktor potensial dan kontributif, yang terkait dengan perilaku inovatif dari perspektif karyawan. Lebih-lebih pada karyawan wanita dalam penelitian di industri manufaktur. 
Joseph Schumpeter berkomentar bahwa pengusaha wanita adalah wanita yang memiliki dorongan batin dan inisiatif diri sikap untuk memulai bisnisnya sendiri (Lai et al., 2010). Lavoie menggambarkan bahwa perempuan wirausahawan sebagai pemimpin dalam bisnis apa pun dan harus melakukan upaya pertama untuk meluncurkan yang baru usaha bisnis, mengelola risiko sehari-hari, menangani keuangan, mengkoordinasikan administrasi, memegang tanggung jawab sosial, dan bertanggung jawab atas manajemennya sehari-hari. Saat ini, semakin banyak wanita yang mencoba menjadi trendsetter dengan menyimpang dari tradisi, peran spesifik gender dan investasi ke dalam usaha bisnis. Lai et al. (2010) menunjukkan semakin banyak bisnis di AS dimiliki oleh wanita. Saat ini, wanita mewakili sekitar setengah dari angkatan kerja AS dan memegang $42,7 \%$ dari posisi manajemen tingkat awal dan menengah. Namun statistic menunjukkan bahwa persentase wanita di tangga perusahaan masih dalam tahap awal dan membuat hingga kurang dari tiga persen di AS. Pengusaha dan profesional wanita menjadi lebih penting dan menonjol dari sebelumnya. Lai et al. (2010) menunjukkan bahwa, "Semakin banyak pengusaha dan professional wanita yang dianggap penting untuk ekonomi pengembangan." Secara global, sebagian besar wanita wiraswasta, dan diperkirakan bahwa perempuan mampu memiliki dan mengelola hingga sepertiga dari semua bisnis di negara maju. Sebuah bukti untuk mendukung klaim ini ditemukan di Langowitz et. Al. (2003) yang menyatakan "Perusahaan yang didirikan dan dimiliki perempuan mewakili peningkatan" persentase bisnis dan bisnis pendapatan di Amerika Serikat. Pada tahun 2000, 38\% bisnis di Amerika Serikat adalah dimiliki oleh perempuan." Lai et al. (2010) lebih lanjut menegaskan bahwa pengusaha perempuan kegiatan dapat memberikan kontribusi yang signifikan terhadap komunitas dan ekonomi mereka, dalam negara maju dan berkembang.

Untuk alasan di atas, studi ini memiliki tiga tujuan. Pertama, tujuan dan kontribusi keseluruhan adalah untuk mempelajari perilaku inovatif dari perspektif karyawan wanita dengan menggunakan organisasi industry manufaktur sebagai area penelitian. Kedua, menurut literature perilaku inovatif dipengaruhi oleh karakteristik pribadi (Kim \& Park, 2015). Studi ini membahas karakteristik pribadi, yakni modal psikologis. Menurut Yu et al. (2019) hanya beberapa penelitian yang mencoba untuk menentukan dampak modal psikologis pada perilaku inovatif karyawan dalam konteks tempat kerja. Ketiga, perilaku innovatif juga dipengaruhi oleh karakteristik organisasi (Masduki Asbari, 2020; Masduki Asbari, Novitasari, Gazali, et al., 2020; Masduki Asbari \& Novitasari, 2020a; Hutagalung, Sopa, et al., 2020; Novitasari, Kumoro, et al., 2020; Novitasari, Yuwono, et al., 2020; Suprapti et al., 2020). Studi ini membatasi karakteristik organisasi pada aspek kepemimpinan.

Secara khusus, studi ini memeriksa apakah dan bagaimana pengaruh kepemipinan dikaitkan dengan modal psikologis karyawan wanita dan perilaku inovatifnya di industry manufaktur. Dengan berfokus pada tiga konstruksi ini, studi berkontribusi pada domain penelitian kinerja inovasi karyawan wanita di industry manufaktur yang masih relative sangat sedikit. Laporan penelitian ini disusun sebagai berikut. Pertama, model konseptual dijelaskan secara singkat. Kedua, konten dan hubungan antar konsep dibahas. Ketiga, metode, analisis statistik dan hasil tes hipotesis empiris disajikan. Bagian terakhir memuat kesimpulan keseluruhan dari penelitian ini. Makalah ini diakhiri dengan diskusi tentang temuan dan rekomendasi untuk penelitian lebih lanjut.

\section{Perilaku Inovatif Individu}

Inovasi adalah fenomena yang sulit untuk didefinisikan dan dipelajari, dan tidak ada konsensus tentang bagaimana mendefinisikan inovasi (Fuglsang, 2010). Salah satu definisi paling awal dari inovasi adalah definisi Schumpeter (Schumpeter, 2008). Schumpeter menyebut inovasi sebagai 'kombinasi baru' layanan, proses kerja, produk dan pasar (Fritsch, 2017; Schumpeter, 2008). Dalam literatur, inovasi dapat mengacu pada sebuah produk atau layanan baru, proses produksi baru, atau struktur atau sistem administrasi baru (Hult et al., 2004). Definisi yang beragam dari inovasi ini menunjukkan berbagai potensi perbedaan antara berbagai jenis inovasi. Sederhananya, inovasi dapat terwujud di mana saja dalam sebuah organisasi. Namun, studi ini membatasi fokusnya pada inovasi yang relevan dengan individu karyawan wanita. Jenis inovasi yang dievaluasi dalam penelitian ini adalah perilaku inovatif individu dalam industry manufaktur. Perilaku inovatif individu menyangkut implementasi inovasi yang berpotensi bermanfaat bagi kinerja pegawai. 
Perilaku inovatif individu berkaitan dengan perilaku karyawan dan kemampuan mereka untuk mengadopsi dan menggunakan ide-ide baru dan berguna di lingkungan kerja mereka (Agistiawati et al., 2020; Hutagalung, Sopa, et al., 2020; Novitasari, Kumoro, et al., 2020; Novitasari, Yuwono, et al., 2020; Suprapti et al., 2020). Dengan demikian, perilaku inovatif individu melakukan sesuatu yang baru yang mewakili perubahan perilaku atau diskontinuitas relatif terhadap pola perilaku organisasi biasa di masa lalu. Akibatnya, domain perilaku inovatif individu terkait dengan praktik karyawan sehari-hari. Inovasi semacam itu secara implisit merupakan fungsi pembelajaran dan penciptaan pengetahuan, yang diintegrasikan ke dalam praktik kerja sehari-hari (Avby \& Kjellström, 2019). Selain itu, tidak ada fokus eksplisit pada waktu implementasi. Inovasi dapat diimplementasikan baik sebagai perubahan satu kali (misalnya untuk improvement kondisional pada situasi tertentu) atau lebih permanen (misalnya prosedur baru yang diperluas untuk semua proses produksi). Inovasi dalam situasi satu waktu dapat dianalogikan dengan istilah literatur sebagai ad hoc innovation (Gallouj \& Weinstein, 1997). Mirip dengan inovasi ad hoc, perilaku inovatif individu mungkin menyertakan beberapa inovasi sementara. Namun, konsep perilaku inovatif individu bisa dimasukkan beberapa elemen yang dapat diulang dalam situasi baru, untuk diimplementasikan dan digeneralisasikan secara lebih permanen (Toivonen et al., 2007). Konsekuensinya, konsep perilaku inovatif individu dalam penelitian ini terbuka untuk berbagai perubahan yang relevan dengan kinerja karyawan. Dengan demikian, perilaku inovatif individu merangkul dan mencerminkan sebuah bentuk spesifik dari aktivitas yang berorientasi perubahan (Battistelli et al., 2013), yang secara eksplisit ditunjukkan pada karyawan dalam implementasi ide-ide baru dan berguna dalam sebuah peran kerja.

\section{Modal psikologis}

Modal psikologis berfokus pada aspek positif dan kekuatan individu dan melabeli mereka secara kolektif sebagai sumber psikologis positif untuk proses inovatif (Luthans et al., 2007a). Modal psikologis pada Gambar 1 adalah karakteristik pribadi kedua yang dapat mempengaruhi perilaku inovatif individu. Konstruksi modal psikologis diambil dari psikologi positif, dan perhatian "siapa kamu" sebagai pribadi (Luthans et al., 2007b). Luthans et al. (2007b) mendeskripsikan modal psikologis sebagai konstruk yang mencakup empat sumber daya psikologis positif tingkat pertama: (i) harapan, (ii) self-efficacy, (iii) ketahanan (resiliensi) dan (iv) optimism (Luthans et al., 2007a). Dimensi harapan dalam modal psikologis adalah suatu keadaan motivasi yang menggambarkan sejauh mana seseorang dapat maju ketika menghadapi rintangan. Self-efficacy adalah kepercayaan individu pada seseorang, berupa "kemampuan untuk melakukan tugas dengan sukses". Ketahanan (resiliensi) mengacu pada kemampuan untuk mengelola kemunduran, mengejar tujuan, dan mencapai hasil yang baik. Optimisme adalah penilaian positif terhadap masa depan (Luthans \& Youssef-Morgan, 2017).

Penelitian sebelumnya telah menghubungkan modal psikologis individu dengan kinerja terkait pekerjaan, termasuk perilaku inovatif individu. Misalnya, Slåtten et al. (2019) menemukan bahwa modal psikologis di antara karyawan berhubungan secara positif dengan perilaku inovatif. Dalam studi lain, ditemukan hubungan positif antara modal psikologis dan kinerja inovatif yang dinilai supervisor di antara karyawan yang dipekerjakan di berbagai bidang (Abbas \& Raja, 2015). Sejalan dengan sebagian besar penelitian sebelumnya, modal psikologis diharapkan dalam konstruk seperti itu "menyediakan gudang sumber daya psikologis yang diperlukan yang membantu secara efektif ide-ide yang berhubungan dengan pekerjaan inovatif" (Abbas \& Raja, 2015). Berdasarkan hal tersebut, maka diajukan hipotesis kedua penelitian ini sebagai berikut:

Hipotesis 1: Modal psikologis berpengaruh signifikan terhadap perilaku inovatif.

\section{Dukungan Otonomi Kepemimpinan/ Leadership Autonomy Support}

Dalam model konseptual pada Gambar 1, dukungan otonomi kepemimpinan mewakili karakteristik organisasi. Secara umum, kepemimpinan merupakan variabel organisasi yang esensial karena mempengaruhi kinerja kreatif karyawan seperti perilaku inovatif individu (M Asbari et al., 2020; Masduki Asbari et al., 2019; Masduki Asbari, Hyun, Wijayanti, et al., 2020; Masduki Asbari, Purba, et al., 2021; Masduki Asbari, Purwanto, Ong, et al., 2020; Fayzhall et al., 2020; Hyun et al., 2020; Nugroho et al., 2020; Nuryanti et al., 2020; Purwanto, Asbari, Prameswari, et al., 2020; Santoso et al., 2019). Dukungan otonomi kepemimpinan dapat mempengaruhi 
motivasi dalam konteks kerja (Gagné \& Deci, 2005). Motivasi ini menarik karena dua alasan. Pertama, seperti disebutkan di atas, perilaku inovatif individu relatif membuat stres dan menuntut tindakan. Kedua, perilaku inovatif individu dapat digambarkan sebagai "perilaku peran ekstra", karena biasanya bukan merupakan kewajiban langsung, juga tidak secara eksplisit dinyatakan dalam kontrak formal atau uraian tugas kerja. Oleh karena itu, kinerja kreatif dalam kaitannya dengan perilaku inovatif individu dapat digambarkan sebagai kerja keras sukarela yang ingin dilakukan oleh karyawan tetapi tidak harus dilakukan. Konsekuensinya, karyawan membutuhkan tingkat ketertarikan tertentu, atau lebih tepatnya, motivasi untuk menjadi kreatif dan inovatif. Aspek terakhir dari motivasi karyawan ini menarik dan sangat relevan dengan konsep dukungan otonomi kepemimpinan. Oleh karena itu, dukungan otonomi kepemimpinan menjadi perhatian khusus untuk keseluruhan tujuan studi ini. Dalam studi ini, dukungan otonomi kepemimpinan mengacu pada persepsi karyawan tentang kualitas hubungan interpersonal karyawan dengan pemimpin mereka. Domain dan fokus dukungan otonomi kepemimpinan adalah konteks kerja interpersonal dan apakah karyawan memandang pemimpin mereka sebagai orang yang memotivasi, dan mendorong mereka untuk bekerja secara mandiri. Tidak mengherankan, karyawan paling sering merasa bahwa pemimpin yang tidak mendukung otonomi menurunkan motivasi batin mereka, sementara pemimpin yang mendukung otonomi meningkatkan motivasi. Oleh karena itu, karena otonomi di tempat kerja dan pemimpin yang mendukung otonomi sangat erat kaitannya dengan motivasi batin karyawan, pemimpin seperti ini paling sering dihargai dan dicari oleh karyawan. Individu yang mencari otonomi di tempat kerja sering mencari lingkungan dan situasi motivasi batin yang memberi mereka kesempatan untuk menentukan nasib mereka sendiri di tempat kerja.

Ada beberapa alasan yang saling terkait mengapa dukungan otonomi kepemimpinan berdampak langsung pada perilaku inovatif individu karyawan (Masduki Asbari, 2015; Masduki Asbari, Fayzhall, et al., 2020; Masduki Asbari, Novitasari, Silitonga, et al., 2020; Masduki Asbari, Prasetya, et al., 2021; Fikri et al., 2020; Kamar et al., 2020; Ong et al., 2020; Purwanto, Budi Santoso, et al., 2020; Purwanto, Pramono, et al., 2020; Purwanto, Asbari, Budi Santoso, et al., 2020). Pertama, dukungan otonomi kepemimpinan berpotensi sebagai "bahan bakar" karyawan dengan motivasi batin yang meningkatkan minat mereka dan mengarahkan mereka untuk fokus pada peningkatan kinerja mereka secara berkesinambungan. Penelitian sebelumnya mendukung pandangan bahwa dukungan otonomi terkait dengan motivasi karyawan dalam konteks kerja (Masduki Asbari, Santoso, et al., 2020; Masduki Asbari, 2019, 2020; Masduki Asbari, Novitasari, Gazali, et al., 2020; Masduki Asbari \& Novitasari, 2020b, 2020c; Basuki et al., 2020; Goestjahjanti et al., 2020; Hutagalung, Asbari, et al., 2020; Jumiran et al., 2020; Maesaroh et al., 2020; Novitasari, Goestjahjanti, et al., 2020; Novitasari, Kumoro, et al., 2020; Novitasari, Sasono, et al., 2020; Novitasari \& Asbari, 2020b, 2020a, 2020c; Silitonga et al., 2020; Sudiyono et al., 2020; Suprapti et al., 2020; Yuwono, Wiyono, et al., 2020, 2020; Zaman et al., 2020). Kedua, karena dukungan otonomi kepemimpinan dikaitkan dengan motivasi positif, maka wajar untuk mengasumsikan bahwa karyawan juga menjadi lebih terlibat dan berdedikasi, yang meningkatkan perilaku inovatif individual mereka. Akibatnya, dengan alasan ini, karyawan berpersepsi bahwa fungsi dukungan otonomi kepemimpinan sejalan dengan motivasi mereka dengan mempromosikan perilaku inovatif individual. Pentingnya motivasi untuk inovasi didukung oleh teori komponensial tentang kreativitas. Dengan teori ini, motivasi seorang individu disarankan menjadi mekanisme utama yang mempengaruhi perilaku inovatif individu (Amabile et al., 2005). Penelitian sebelumnya menunjukkan bahwa pemimpin yang mendukung otonomi memiliki dampak positif pada kinerja karyawan (Amabile et al., 2005; Hocine \& Zhang, 2014) Penelitian sebelumnya juga telah mengungkapkan bahwa ketika karyawan mengalami kebalikan dari otonomi (tidak diberikan otonomi) di tempat kerja, ini berdampak buruk pada inovasi (Hocine \& Zhang, 2014). Akibatnya, berdasarkan penelitian sebelumnya, ada beberapa alasan yang baik untuk mengasumsikan bahwa ketika karyawan memandang dukungan otonomi kepemimpinan dengan cara yang positif maka akan berdampak positif pada perilaku inovatif individual. Penalaran ini mengarah pada hipotesis kedua penelitian ini, yakni:

Hipotesis 2: Leadership autonomy support berpengaruh signifikan terhadap perilaku inovatif. 
Karena para pemimpin adalah manajer yang berperan secara formal dalam organisasi, maka mereka secara signifikan mempengaruhi bawahannya (Kanat-Maymon \& Reizer, 2017). Bahkan sebagai "faktor dominan" (Terje Slåtten et al., 2019). Kepemimpinan adalah sumber daya manajemen kunci yang berinteraksi dengan sumber daya lain (Choi, 2020), seperti sumber daya yang terdiri dari modal psikologis. Sebagaimana dibahas dalam kaitannya dengan hipotesis sebelumnya dalam studi ini, kepemimpinan diharapkan dapat mempengaruhi perilaku inovatif karyawan. Di bawah ini, disarankan bahwa hubungan ini juga bekerja melalui dampak leadership autonomy support (karakteristik organisasi) terhadap modal psikologis (karakteristik pribadi), sebagaimana yang ditunjukkan pada Gambar 1.

Literatur mendefinisikan konsep modal psikologis sebagai keadaan psikologis positif seorang individu (Luthans \& Youssef-Morgan, 2017). Definisi itu sebagai sebuah keadaan psikologis dan menyiratkan bahwa modal psikologis tidak statis atau tetap, namun justru fleksibel dan dinamis. Akibatnya, sumber daya individu yang terdiri dari modal psikologis, berubah sesuai dengan faktor-faktor tertentu. Luthans et al. (2007a) mendukung pandangan ini dengan menyatakan bahwa modal psikologis adalah "variable yang terbuka untuk pengembangan dan dapat dikelola untuk fektivitas kinerja". Dengan penalaran ini, diharapkan leadership autonomy support bisa positif "mengembangkan" atau "mengelola" modal psikologis karyawan. Penelitian saat ini hendak menguji hubungan khusus ini dalam dunia industry manufaktur. Meskipun sangat sedikit penelitian yang telah dilakukan, penelitian sebelumnya menunjukkan adanya hubungan antara leadership autonomy support (dukungan otonomi kepemimpinan) dan modal psikologis. Pertama, ketika karyawan menganggap dukungan otonomi kepemimpinan di organisasi mereka positif, itu mencerminkan persepsi lingkungan kerja yang otonom. Seperti dibahas di atas, lingkungan kerja otonom (di mana dukungan otonomi kepemimpinan adalah bagiannya) secara positif terkait dengan modal psikologis. Misalnya, dalam sebuah studi oleh Choi (2020), penulis tersebut menemukan hubungan yang signifikan dan kuat antara lingkungan kerja otonom dan modal psikologis karyawan industry otomotif di Korea. Menariknya, dalam artikel ini penulis tersebut menjelaskan lingkungan kerja yang otonom sebagai bagian dari tempat kerja yang "memberikan pilihan" kepada karyawan dan mendorong karyawan untuk mengambil "inisiatif pribadi". Oleh karena itu, berdasarkan penelitian yang sangat relevan sebelumnya, hipotesis ketiga pada penelitian ini adalah sebagai berikut:

Hipotesis 3: Leadership autonomy support berpengaruh signifikan terhadap modal psikologis.

Perilaku inovatif dipengaruhi oleh faktor penentu pribadi (internal) dan eksternal (Abdullah et al., 2016). Seperti yang diperdebatkan di seluruh pembahasan hipotesis sebelumnya, bahwa modal psikologis (karakteristik pribadi) berhubungan positif dengan perilaku inovatif individu (Masduki Asbari, Novitasari, et al., 2021; Hutagalung et al., 2021; Johan et al., 2021; Novitasari, Asbari, et al., 2021; Novitasari, Haque, et al., 2021; Novitasari, Supriatna, et al., 2021; Novitasari \& Asbari, 2021; Silitonga et al., 2021). Selain itu, bahwa leadership autonomy support, sebagai determinan eksternal (karakteristik organisasi) mengembangkan dan meningkatkan modal psikologis karyawan. Berdasarkan alasan dan asumsi ini, wajar untuk mengasumsikan bahwa modal psikologis memainkan peran mediasi dalam hubungan antara leadership autonomy support dan perilaku inovatif individu karyawan. Khususnya, saat modal psikologis karyawan meningkat karena perkembangan positif yang berasal dari leadership autonomy support. Hal ini kemudian meningkatkan perilaku inovasi mereka. Penulis belum mengetahui adanya penelitian sebelumnya yang secara khusus menguji interaksi antara variabel-variabel ini dalam unit analisis karyawan wanita. Namun, penelitian sebelumnya telah menemukan bahwa modal psikologis memediasi hubungan antara kepemimpinan otentik dan perilaku inovatif (Novitasari, Kumoro, et al., 2020; Purwanto et al., 2021). Dengan demikian, mengingat peran penting yang dilaporkan dalam literatur, modal psikologis diharapkan dapat memediasi hubungan antara leadership autonomy support dan perilaku inovatif individu karyawan. Oleh karena itu, hipotesis keempat pada penelitian ini adalah sebagai berikut:

Hipotesis 4: Leadership autonomy support berpengaruh signifikan terhadap perilaku inovatif melalui modal psikologis sebagai mediator. 


\section{Kerangka Konsep Penelitian}

Menurut Sekaran \& Bougie (2003) kerangka teoritis merupakan fondasi di mana seluruh proyek penelitian didasarkan. Dari kerangka teoritis bisa disusun hipotesis yang dapat diuji untuk mengetahui apakah teori yang dirumuskan valid atau tidak. Lalu kemudian selanjutnya akan dapat diukur dengan analisis statistik yang tepat. Mengacu pada teori dan penelitian terdahulu terdapat hubungan antara variable-variabel berikut: leadership autonomy support yang mengacu pada parameter penelitian Slåtten et al. (2020), modal psikologis yang mengacu pada parameter penelitian Luthans \& YoussefMorgan (2017), dan perilaku inovatif mengacu pada parameter penelitian Janssen (2000) dan Scott \& Bruce (1994). Untuk itu, penulis membangun model penelitian sebagai mana disebut pada Gambar 1 berikut:

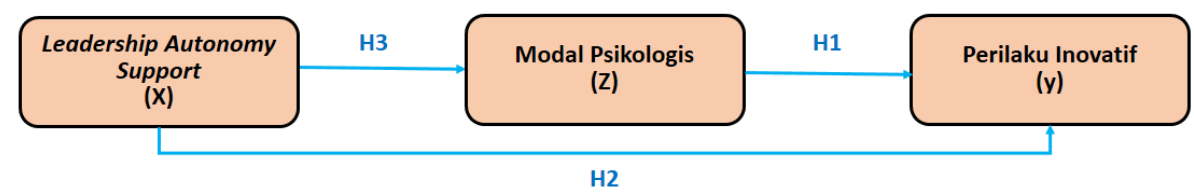

\section{Gambar 1. Model Penelitian}

\section{METODE PENELITIAN}

\section{Definisi Operasional Variabel dan Indikator}

Metode yang digunakan dalam penelitian ini adalah metode kuantitatif dengan teknik survey, dimana penelitian dilakukan dalam ruang alamiah atau bukan buatan. Studi ini berkarakter probablistik yang menggunakan analisis regresi berganda. Metode yang digunakan untuk menganalisis data adalah regresi linier berganda dengan serangkaian uji instrument. Menurut Sugiyono (2017), metode penelitian kuantitatif dapat diartikan sebagai metode penelitian yang berlandaskan pada filsafat positivisme, digunakan untuk meneliti pada populasi atau sampel tertentu. Teknik pengambilan sampel dilakukan secara acak sederhana (simple random sampling), pengumpulan data menggunakan instrumen penelitian, analisis data bersifat kuantitatif/statistik dengan tujuan untuk menguji hipotesis yang telah ditetapkan. Dilakukan pengumpulan data dengan mengedarkan angket kepada seluruh karyawan wanita pada salah satu perusahaan manufaktur di Tangerang. Instrumen yang digunakan untuk mengukur leadership autonomy support diadaptasi dari Slåtten et al. (2020) dengan menggunakan 5 items (X1$\mathrm{X} 5$ ). Variabel leadership autonomy support didefinisikan sebagai persepsi karyawan tentang kualitas hubungan interpersonal mereka dengan pemimpinnya (T. Slåtten et al., 2020). Variabel leadership autonomy support dijelaskan dalam lima buah items berikut ini: (X1) "Pemimpin saya memberi saya otoritas atas masalah di area kerja saya"; (X2) "Pemimpin saya mau mendengarkan saya"; (X3) "Pemimpin saya mendorong saya untuk mengambil inisiatif"; (X4) "Pemimpin saya peduli bahwa pekrjaan saya berorientasi pada tujuan"; (X5) "Pemimpin saya selalu memberikan motivasi".

Instrumen yang digunakan untuk mengukur modal psikologis diadaptasi dari Luthans \& Youssef-Morgan (2017) dengan menggunakan 4 items (Z1-Z4). Modal psikologis didefinisikan sebagai keadaan perkembangan psikologis positif seseorang yang ditandai dengan efikasi diri, optimisme, harapan dan ketahanan (Luthans \& Youssef-Morgan, 2017). Variabel modal psikologis ini dijelaskan dalam empat buah items, yakni: (Z1) "Saya merasa yakin bahwa saya dapat menetapkan tujuan untuk diri saya sendiri di area kerja saya"; (Z2) "Saya optimis tentang masa depan saya di organisasi ini"; (Z3) "Ketika dihadapkan pada tantangan dalam pekerjaan saya, saya dapat menemukan solusi alternatif untuk itu"; (Z4) "Saya dapat menemukan cara alternatif untuk mencapai tujuan saya".

Instrumen perilaku inovatif diadaptasi dari Janssen (2000) dan Scott \& Bruce (1994) dengan menggunakan 5 items (Y1-Y5). Perilaku inovatif (individu) didefinisikan sebagai Perilaku karyawan dan kemampuannya untuk mengadopsi dan menggunakan ide-ide baru dan berguna dalam pekerjaan mereka (Janssen, 2000; Scott \& Bruce, 1994). Variabel perilaku inovatif individu ini dijelaskan dalam lima buah items, yakni (Y1) Saya menciptakan ide-ide baru untuk memecahkan masalah dalam pekerjaan saya; (Y2) Saya mencari metode atau teknik kerja baru untuk menyelesaikan pekerjaan saya; (Y3) Saya menyelidiki dan menemukan cara untuk menerapkan ide-ide saya; (Y4) Saya mempromosikan ide-ide saya agar orang lain dapat menggunakannya dalam pekerjaan mereka; (Y5) Saya mencoba ide-ide baru dalam pekerjaan saya. 
Model penelitian dapat dilihat sebagaimana pada Gambar 1. Angket didesain tertutup kecuali untuk pertanyaan/pernyataan mengenai identitas responden yang berupa angket semi terbuka. Tiap item pertanyaan/pernyataan tertutup diberikan lima opsi jawaban, yaitu: sangat setuju (SS) skor 5, setuju (S) skor 4, netral (N) skor 3, tidak setuju (TS) skor 2, dan sangat tidak setuju (STS) skor 1. Metode untuk mengolah data adalah dengan PLS dan menggunakan software SmartPLS versi 3.0 sebagai toolnya. Kuesioner penelitian ini diambil dari butir-butir item dari variabel yang sudah mapan, sehingga dinilai tidak diperlukan lagi melakukan studi pendahuluan, tetapi peneliti langsung melakukan pengambilan data dari unit analisis yang menjadi subyek penelitian.

\section{Populasi dan Sampel}

Populasi dalam penelitian ini adalah karyawan wanita dari salah satu industri manufaktur di Tangerang yang jumlahnya 113 orang. Kuesioner, sebagaimana disebutkan secara detil pada bagian definisi operasional di atas, disebarkan dengan teknik simple random sampling. Hasil kuesioner yang kembali dan valid sebanyak adalah 87 sampel. Jadi jumlah sampel adalah $77 \%$ dari jumlah populasi.

\section{HASIL PENELITIAN \\ Deskripsi Sampel}

Total ada 87 karyawan wanita yang berpartisipasi. Status kepegawaian responden beragam, $48 \%$ di antaranya pegawai kontrak dan $52 \%$ sisanya adalah pegawai tetap. Responden memiliki kelompok umur yang berbeda-beda, berkisar antara di bawah usia 29 tahun (23.8\%), 30-49 tahun (48.6\%), dan lebih dari usia 50 tahun (27.6\%). Lama kerja responden juga beragam, 34.3\% di antaranya di bawah 5 tahun, $49.5 \%$ sudah bekerja antara 5-10 tahun, dan 16.2\% sisanya telah bekerja lebih dari 10 tahun. Pendidikan tertinggi responden adalah lulusan sarjana sebanyak 1.9\%, lulusan SMP 22.9\%, mayoritas setingkat SLTA (SMA/SMK) yakni $75.2 \%$.

\section{Table 1. Deskripsi Sampel}

\begin{tabular}{|c|c|c|c|}
\hline \multicolumn{2}{|c|}{ Kriteria } & Jml. & $\%$ \\
\hline Usia & $\begin{array}{l}<29 \text { thn. } \\
30-49 \text { thn. } \\
>50 \text { thn. }\end{array}$ & $\begin{array}{l}21 \\
42 \\
24\end{array}$ & $\begin{array}{l}23.8 \% \\
48.6 \% \\
27.6 \%\end{array}$ \\
\hline Masa kerja sebagai karyawan & $\begin{array}{l}<5 \text { thn. } \\
5-10 \text { thn. } \\
>10 \text { thn. }\end{array}$ & $\begin{array}{l}30 \\
43 \\
14\end{array}$ & $\begin{array}{l}34.3 \% \\
49.5 \% \\
16.2 \%\end{array}$ \\
\hline Ijazah tertinggi & $\begin{array}{l}\text { SMP } \\
\text { SLTA (SMA/SMK) } \\
\geq \text { S1 }\end{array}$ & $\begin{array}{c}20 \\
65 \\
2\end{array}$ & $\begin{array}{c}22.9 \% \\
75.2 \% \\
1.9 \%\end{array}$ \\
\hline
\end{tabular}

Sumber: Data Diolah (2021)

\section{Hasil Uji Validitas dan Reliabilitas Indikator Penelitian}

Tahap pengujian model pengukuran meliputi pengujian validitas konvergen, validitas diskriminan. Sementara untuk menguji reliabilitas konstruk digunakan nilai cronbach's alpha dan composite reliability. Hasil analisis PLS dapat digunakan untuk menguji hipotesis penelitian jika seluruh indikator dalam model PLS telah memenuhi syarat validitas konvergen, validitas deskriminan dan uji reliabilitas.

\section{Pengujian Validitas Konvergen}

Uji validitas konvergen dilakukan dengan melihat nilai loading factor masing-masing indikator terhadap konstruknya. Pada sebagian besar referensi, bobot faktor sebesar 0.7 atau lebih dianggap memiliki validasi yang cukup kuat untuk menjelaskan konstruk laten (Chin, 1998; Ghozali, 2014; Hair et al., 2010). Pada penelitian ini batas minimal besarnya loading factor yang diterima adalah 0.7 , dan dengan syarat nilai AVE setiap konstruk $>0.5$ (Ghozali, 2014). Setelah melalui pengolahan SmartPLS 3.0, seluruh indikator telah memiliki nilai loading factor di atas 0.7 dan nilai AVE di atas 0.5 . Model fit atau valid dari penelitian ini dapat dilihat pada Gambar 2. Jadi dengan demikian, validitas konvergen dari model penelitian ini sudah memenuhi syarat. Nilai loadings, cronbach's alpha, composite reliability dan AVE setiap konstruk selengkapnya dapat dilihat Tabel 2. 


\section{Pengujian Validitas Deskriminan}

Discriminant validity dilakukan untuk memastikan bahwa setiap konsep dari masing-masing variabel laten berbeda dengan variabel laten lainnya. Model mempunyai discriminant validity yang baik jika nilai kuadrat AVE masing-masing konstruk eksogen (nilai pada diagonal) melebihi korelasi antara konstruk tersebut dengan konstruk lainnya (nilai di bawah diagonal) (Ghozali, 2014). Hasil pengujian discriminant validity adalah dengan menggunakan nilai kuadrat AVE, yakni dengan melihat FornellLarcker Criterion Value diperoleh sebagaimana ditunjukkan pada Tabel 3. Hasil uji validitas deskriminan pada tabel 3 di atas menunjukkan bahwa seluruh konstruk telah memiliki nilai akar kuadrat AVE di atas nilai korelasi dengan konstruk laten lainnya (melalui kriteria Fornell-Larcker). Demikian juga nilai cross-loading seluruh item dari suatu indikator lebih besar dari item indikator lainnya sebagaimana disebut pada Tabel 4, sehingga dapat disimpulkan bahwa model telah memenuhi validitas deskriminan (Fornell \& Larcker, 1981).

Selanjutnya dilakukan evaluasi collinearity untuk mengetahui ada tidaknya masalah collinearity pada model. Untuk menemukan collinearity tersebut, diperlukan statistik collinearity VIF dari setiap konstruk. Jika VIF lebih dari 5, maka model memiliki collinearity (Hair et al., 2014). Seperti yang ditunjukkan pada Tabel 4, semua skor VIF kurang dari 5, yakni hasil dari model struktural collinearity mengungkapkan nilai VIF di bawah 2. Hal ini menunjukkan bahwa model penelitian ini tidak ada masalah multikolinearitas.

\section{Pengujian Reliabilitas Konstruk}

Reliabilitas konstruk dapat dinilai dari nilai cronbach's alpha dan composite reliability dari masing-masing konstruk. Nilai composite reliability dan cronbach's alpha yang disarankan adalah lebih dari 0.7 (Ghozali, 2014). Hasil uji reliabilitas pada tabel 2 di atas menunjukkan bahwa seluruh konstruk telah memiliki nilai composite reliability dan cronbach's alpha lebih besar dari 0.7 (>0.7). Kesimpulannya, seluruh konstruk telah memenuhi reliabilitas yang dipersyaratkan.

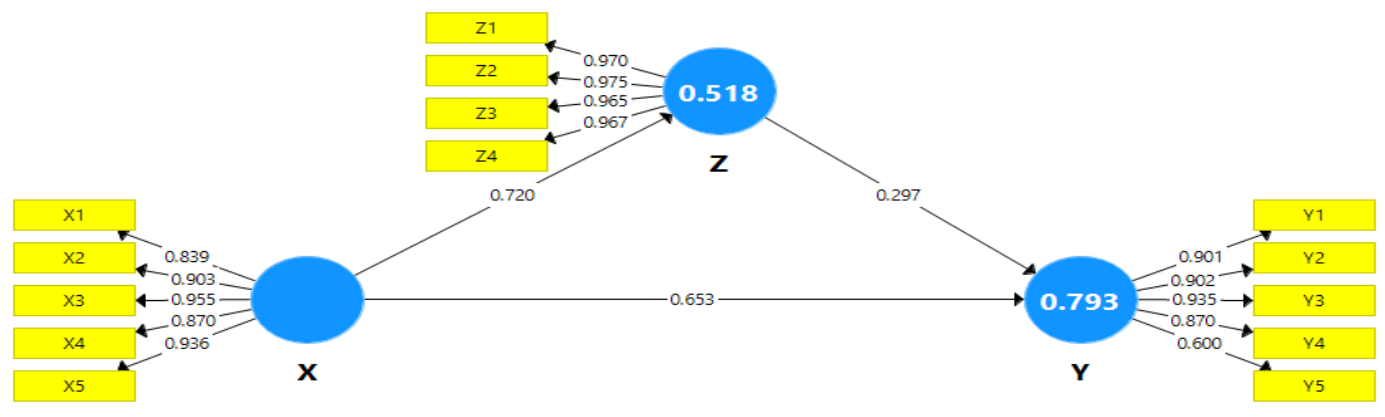

Gambar 2. Model Penelitian Valid

Sumber: Hasil Pengolahan SmartPLS 3.0 (2021)

Tabel 2. Items Loadings, Cronbach's Alpha, Composite Reliability, and Average Variance Extracted (AVE)

\begin{tabular}{|c|c|c|c|c|c|}
\hline Variables & Items & Loadings & $\begin{array}{l}\text { Cronbach's } \\
\text { Alpha }\end{array}$ & $\begin{array}{l}\text { Composite } \\
\text { Reliability }\end{array}$ & AVE \\
\hline \multirow[t]{5}{*}{ Leadership Autonomy Support (X) } & $\mathrm{X} 1$ & 0.839 & \multirow[t]{5}{*}{0.942} & \multirow[t]{5}{*}{0.956} & \multirow[t]{5}{*}{0.813} \\
\hline & $\mathrm{X} 2$ & 0.903 & & & \\
\hline & $\mathrm{X} 3$ & 0.955 & & & \\
\hline & $\mathrm{X} 4$ & 0.870 & & & \\
\hline & $\mathrm{X} 5$ & 0.936 & & & \\
\hline \multirow[t]{4}{*}{ Modal Psikologis (Z) } & $\mathrm{Z1}$ & 0.970 & \multirow[t]{4}{*}{0.978} & \multirow[t]{4}{*}{0.984} & \multirow[t]{4}{*}{0.939} \\
\hline & $\mathrm{Z} 2$ & 0.975 & & & \\
\hline & $\mathrm{Z3}$ & 0.965 & & & \\
\hline & $\mathrm{Z4}$ & 0.967 & & & \\
\hline \multirow[t]{5}{*}{ Perilaku Inovatif (Y) } & Y1 & 0.901 & \multirow[t]{5}{*}{0.900} & \multirow[t]{5}{*}{0.927} & \multirow[t]{5}{*}{0.723} \\
\hline & Y2 & 0.902 & & & \\
\hline & Y3 & 0.935 & & & \\
\hline & Y4 & 0.870 & & & \\
\hline & Y5 & 0.600 & & & \\
\hline
\end{tabular}

Sumber: Hasil Pengolahan SmartPLS 3.0 (2021 
Tabel 3. Discriminant Validity

\begin{tabular}{lccc}
\hline Variables & $\mathbf{X}$ & $\mathbf{Y}$ & $\mathbf{Z}$ \\
\hline & & & \\
Leadership Autonomy Support (X) & 0.902 & & \\
Perilaku Inovatif(Y) & 0.866 & 0.850 & 0.969 \\
Modal Psikologis (Z) & 0.720 & 0.767 & \\
\hline
\end{tabular}

Sumber: Hasil Pengolahan SmartPLS 3.0 (2021)

Tabel 4. Collinearity Statistkreativitas individu s (VIF)

\begin{tabular}{|c|c|c|c|}
\hline Variables & $\mathbf{X}$ & $\mathbf{Y}$ & $\mathbf{Z}$ \\
\hline $\begin{array}{l}\text { Leadership Autonomy Support (X) } \\
\text { Perilaku Inovatif }(\mathrm{Y}) \\
\text { Modal Psikologis }(\mathrm{Z})\end{array}$ & & $\begin{array}{l}2.074 \\
2.074\end{array}$ & 1.000 \\
\hline
\end{tabular}

Sumber: Hasil Pengolahan SmartPLS 3.0 (2021)

Tabel 5. Nilai $R$ Square

\begin{tabular}{lcl} 
Variables & R Square & R Square Adjusted \\
\hline Perilaku Inovatif (Y) & 0.793 & 0.788 \\
Modal Psikologis (Z) & 0.518 & 0.512
\end{tabular}

Sumber: Hasil Pengolahan SmartPLS 3.0 (2021)

Tabel 6. Hypotheses Testing

\begin{tabular}{llccccc}
\hline Hypotheses & Relationship & Beta & SE & T Statistics & P-Values & Decision \\
\hline H1 & Z -> Y & 0.297 & 0.119 & 2.502 & 0.013 & Supported \\
H2 & X -> Y & 0.653 & 0.109 & 5.994 & 0.000 & Supported \\
H3 & X -> Z & 0.720 & 0.073 & 9.902 & 0.000 & Supported \\
H4 & X -> Z -> Y & 0.214 & 0.096 & 2.231 & 0.026 & Supported \\
\hline
\end{tabular}

Sumber: Hasil Pengolahan SmartPLS 3.0 (2021)

\section{Pengujian Hipotesis}

Pengujian hipotesis dalam PLS disebut juga sebagai uji inner model. Uji ini meliputi uji signifikansi pengaruh langsung dan tidak langsung serta pengukuran besarnya pengaruh variabel eksogen terhadap variabel endogen. Untuk mengetahui pengaruh leadership autonomy support terhadap perilaku inovatif individu karyawan wanita melalui modal psikologis sebagai variable mediasi dibutuhkan uji pengaruh langsung dan tidak langsung. Uji pengaruh dilakukan dengan menggunakan uji t-statistik dalam model analisis partial least squared (PLS) dengan menggunakan bantuan software SmartPLS 3.0. Dengan teknik boothstrapping, diperoleh nilai $R$ Square dan nilai uji signifikansi sebagaimana Tabel 5 dan Tabel 6.

Berdasarkan Tabel 5 di atas, nilai $R$ Square modal psikologis $(Z)$ sebesar 0.518 yang berarti bahwa variable modal psikologis (Z) mampu dijelaskan oleh variabel leadership autonomy support $(\mathrm{X})$ sebesar $51.8 \%$, sedangkan sisanya sebesar $48.2 \%$ dijelaskan oleh variabel lain yang tidak dibahas dalam penelitian ini. Pengaruh ini terhitung sebagai level pengaruh yang kuat. Sementara itu, nilai $R$ Square perilaku inovatif (Y) sebesar 0.793 yang berarti bahwa variabel perilaku inovatif (Y) mampu dijelaskan oleh variabel leadership autonomy support $(\mathrm{X})$ dan modal psikologis $(\mathrm{Z})$ sebesar 79.3\%, sedangkan sisanya sebesar $20.7 \%$ dijelaskan oleh variabel lain yang tidak dibahas dalam penelitian ini. Pengaruh ini terhitung sebagai level pengaruh yang kuat. Sedangkan Tabel 6 menampilkan $t$-statistics dan $p$ values yang menunjukkan pengaruh antar variable penelitian yang telah disebutkan. 


\section{PEMBAHASAN}

Hasil analisis data menunjukkan bahwa: pertama, modal psikologis berpengaruh positif dan signifikan terhadap perilaku inovatif. Hal ini terbukti dengan nilai $t$-statistics 2.502 lebih besar dari 1.96 dan nilai p-values sebesar 0.013 lebih kecil dari 0.05. Kesimpulannya hipotesis H1 diterima. Kedua, leadership autonomy support berpengaruh positif dan signifikan terhadap perilaku inovatif. Terbukti dengan nilai $t$-statistics 5.994 lebih besar dari 1.96 dan nilai p-values sebesar 0.000 lebih kecil dari 0.05 . Kesimpulannya hipotesis $\mathbf{H 2}$ diterima. Ketiga, leadership autonomy support berpengaruh positif dan signifikan terhadap modal psikologis. Hal ini terbukti dengan nilai $t$-statistics 9.902 lebih besar dari 1.96 dan nilai p-values sebesar 0.000 lebih kecil dari 0.05. Kesimpulannya hipotesis $\mathbf{H 3}$ diterima. Keempat, leadership autonomy support berpengaruh positif dan signifikan terhadap perilaku inovatif melalui modal psikologis. Hal ini terbukti dengan nilai $t$-statistics 2.231 lebih besar dari 1.96 dan nilai p-values sebesar 0.026 lebih kecil dari 0.05. Kesimpulannya hipotesis $\mathbf{H 4}$ diterima.

Studi ini bertujuan untuk meningkatkan pemahaman dan penerapan aplikasi tentang dasardasar inovasi dalam organisasi manufaktur. Kontribusi dapat diringkas dalam tiga bagian. Pertama, berbeda dengan kebanyakan penelitian sebelumnya pada tingkat inovasi organisasi, penelitian ini berfokus pada inovasi dari perspektif individu karyawan, khususnya karyawan wanita. Dengan demikian, hasil studi ini memperdalam dan memperluas wawasan literature tentang pemahaman dan praktik inovasi pada karyawan wanita di industry manufaktur. Karena sejatinya, di banyak indutri manufaktur khususnya di area komoditas alas kaki dan garmen, mayoritas karyawannya adalah berjenis kelamin wanita. Oleh karena itu, kepemimpinan dan modal psikologis ini merupakan sumber daya utama inovasi perusahaan. Kedua, penelitian sebelumnya terbatas pada manifestasi perilaku inovasi atau yang disebut penelitian ini perilaku inovatif individu. Meskipun perilaku inovatif individu merupakan aspek yang menarik, penelitian ini memperluas penelitian sebelumnya karena meningkatkan pengetahuan kita tentang faktor-faktor yang berdampak pada karyawan, yakni proses kognitif yang terkait dengan perilaku inovatif individu. Dengan memasukkan konsep modal psikologis, penelitian ini menawarkan wawasan tentang hubungan antara premis dasar modal psikologis dan perilaku inovatif individu.

Sejalan dengan penelitian sebelumnya, perilaku inovatif individu dalam penelitian ini didefinisikan sebagai "implementasi ide-ide baru dan berguna dalam peran kerja" (Battistelli et al., 2013). Sebagaimana disebutkan di atas, perilaku inovatif individu mencakup berbagai manifestasi perilaku "kebaruan" dalam bekerja. Secara khusus, "kebaruan" berkisar dari inovasi inkremental (minor) di satu sisi, hingga inovasi radikal (besar) di sisi lain. Demikian pula, aspeknya disebut sebagai "di dalam" peran kerja dalam definisi perilaku inovatif individu mencakup berbagai macam "waktu dan tempat" dimana "kebaruan" atau inovasi terjadi. Secara khusus, istilah "di dalam" peran kerja dapat mencakup inovasi oleh karyawan garis depan (misalnya menemukan cara baru untuk mengelola produksi pengemasan) serta 'dalam' pekerjaan di belakang panggung (misalnya rutinitas administratif baru atau proses kerja internal). Dengan demikian, definisi perilaku inovatif individu dalam penelitian ini menyentuh salah satu definisi paling awal dari inovasi, yang disediakan oleh Schumpeter (2008), yang menggambarkan inovasi dalam arti luas sebagai implementasi dari kombinasi layanan baru, proses di tempat kerja, produk dan pasar. Dengan memasukkan modal psikologis, studi ini juga memberikan wawasan baru tentang bagaimana faktor pribadi, secara individu dan kolektif, dapat mempengaruhi kreativitas individu dan perilaku inovatif karyawan.

\section{SIMPULAN}

Studi ini memberikan kontribusi bagi pemahaman dan praktik inovasi dalam organisasi industry manufaktur dari perspektif individu karyawan wanita. Secara teori, studi ini menguatkan teori inovasi yang berlaku di industri manufaktur dengan detil temuan mengungkapkan asosiasi multifaset antara leadership autonomy support, modal psikologis, dan perilaku inovatif karyawan wanita di industry manufaktur di Tangerang. Telah terbukti bahwa (i) variabel modal psikologis berpengaruh positif dan signifikan terhadap perilaku inovatif, (ii) leadership autonomy support berpengaruh positif dan signifikan terhadap perilaku inovatif, (iii) leadership autonomy support berpengaruh positif dan signifikan terhadap modal psikologis, (iv) leadership autonomy support berpengaruh positif dan signifikan terhadap perilaku inovatif melalui modal psikologis karyawan di industry manufaktur di Tangerang. Secara praksis, studi ini membuktikan kesesuaian analisis Lai et al. 
(2010) yang menyimpulkan bahwa di era modern, semakin banyak pengusaha dan professional wanita yang dianggap penting untuk ekonomi pengembangan. Studi ini membuktikan bahwa perusahaan yang digerakkan dan dimiliki jumlah wanita yang signifikan mewakili peningkatan persentase keuntungan bisnis dan dapat memberikan kontribusi yang signifikan terhadap komunitas dan ekonomi mereka, khususnya dalam negara berkembang seperti Indonesia.

\section{SARAN}

Penelitian ini memiliki beberapa keterbatasan. Pertama, penelitian ini menganalisis pengaruh leadership autonomy support terhadap perilaku inovatif individu karyawan wanita di industry manufaktur baik secara langsung maupun tidak langsung melalui variabel modal psikologis. Karena mungkin ada beberapa variabel lain (seperti motivasi, kompetensi, manajemen pengetahuan, budaya organisasi, dan lain-lain) yang mempengaruhi perilaku inovatif individu. Penulis sangat merekomendasikan untuk menemukan, mengeksplorasi, dan menganalisisnya pada penelitianpenelitian berikutnya. Kedua, penelitian ini dilakukan di industri pabrikan manufaktur dan mungkin tidak bisa digeneralisasi ke industri lain. Oleh karena itu, sangat disarankan untuk melakukan penelitian lebih lanjut tentang topik ini di industri lain. Mungkin dapat ditambahkan ke seluruh wilayah, atau di negara lain, atau diperbandingan antara UKM dan organisasi besar.

\section{REFERENSI}

Abbas, M., \& Raja, U. (2015). Impact of psychological capital on innovative performance and job stress. Canadian Journal of Administrative Sciences/Revue Canadienne Des Sciences de l'Administration, 32(2), 128-138.

Abdullah, I., Omar, R., \& Panatik, S. A. (2016). A literature review on personality, creativity and innovative behavior. International Review of Management and Marketing, 6(1S), 177-182.

Agistiawati, E., Asbari, M., Basuki, S., Yuwono, T., \& Chidir, G. (2020). Exploring the Impact of Knowledge Sharing and Organizational Culture on Teacher Innovation Capability. International Journal of Science and Management Studies (IJSMS), 3(3), 62-77. http://www.ijsmsjournal.org/volume3-issue3.html

Amabile, T. M., Barsade, S. G., Mueller, J. S., \& Staw, B. M. (2005). Affect and creativity at work. Administrative Science Quarterly, 50(3), 367-403.

Asbari, M, Wijayanti, L. M., Hyun, C. C., Purwanto, A., Santoso, P. B., Bernarto, I., Pramono, R., \& Fayzhall, M. (2020). The role of knowledge transfer and organizational learning to build innovation capability: Evidence from Indonesian automotive industry. International Journal of Control and Automation, 13(1), 19-322.

Asbari, Masduki. (2015). Fokus Satu Hebat. Penerbit Dapur Buku.

Asbari, Masduki. (2019). Pengaruh kepemimpinan transformasional dan iklim organisasi terhadap kinerja dosen. JOCE IP, 13(2), 172-186. http://jurnal.ipem.ac.id/index.php/joce$\mathrm{ip} /$ article/view/187

Asbari, Masduki. (2020). Is Transformational Leadership Suitable for Future Organizational Needs? International Journal of Sociology, Policy and Law (Ijospl), 01(01), 51-55. https://ijospl.org/index.php/ijospl/article/view/17

Asbari, Masduki, Fayzhall, M., Goestjahjanti, F. S., Winanti, Yuwono, T., Hutagalung, D., Basuki, S., Maesaroh, S., Mustofa, Chidir, G., Yani, A., \& Purwanto, A. (2020). Peran Kepemimpinan Transformasional Dan Organisasi Pembelajaran Terhadap Kapasitas Inovasi Sekolah. EduPsyCouns: Journal of Education, Psychology and Counseling, 2(1), 6724-6748. https://ummaspul.e-journal.id/Edupsycouns/article/view/421

Asbari, Masduki, Hyun, C. C., Wijayanti, L. M., Winanti, Fayzhall, M., \& Putra, F. (2020). Hard Skills dan Soft Skills: Apa Membangun Inovasi Guru Sekolah Islam? Journal EVALUASI, 4(1), 143172.

Asbari, Masduki, \& Novitasari, D. (2020a). Pengaruh Aktivitas Berbagi Pengetahuan dan Mediasi Budaya terhadap Kemampuan Inovasi Guru. Jurnal Manajemen Dan Supervisi Pendidikan, 5(1), 324-334. http://journal2.um.ac.id/index.php/jmsp/article/view/15253 
Asbari, Masduki, \& Novitasari, D. (2020b). Pengaruh Kesiapan untuk Berubah di Masa Pandemi Covid-19: Apa yang Dibutuhkan Pemimpin untuk Menjaga Kinerja. Jurnal Ekonomika: Manajemen, Akuntansi, Dan Perbankan Syari'ah, 9(2), 1-17. https://doi.org/https://doi.org/10.24903/je.v9i2.932

Asbari, Masduki, \& Novitasari, D. (2020c). The Role of Readiness for Change on Part-Timer Employee Performance: Analysis of Transformational Leadership Practice in Convection Industry. Journal of Communication Education (JOCE), 14(02). http://jurnal.ipem.ac.id/index.php/joceip/article/view/220

Asbari, Masduki, Novitasari, D., Gazali, G., Silitonga, N., \& Pebrina, E. T. (2020). Analisis Kesiapan untuk Berubah di Masa Pandemi Covid-19: Studi Pengaruh Kepemimpinan Transformasional terhadap Kinerja Karyawan. Jurnal Perspektif, 18(2), 147-159. https://ejournal.bsi.ac.id/ejurnal/index.php/perspektif/article/view/8576

Asbari, Masduki, Novitasari, D., \& Pebrina, E. T. (2021). Pengaruh Mediasi Mental Kesiapan untuk Berubah dan Work-Family Conflict terhadap Kinerja Karyawan di Masa Pandemi Covid-19. Mega Aktiva: Jurnal Ekonomi Dan Manajemen, 10(1), 24-38. https:/megaaktiva.umkendari.ac.id/index.php/Jurnal/article/view/123

Asbari, Masduki, Novitasari, D., Silitonga, N., \& Sutardi, D. (2020). ANALISIS READINESS FOR CHANGE TERHADAP KINERJA: PERSPEKTIF KARYAWAN KONTRAK DI MASA PANDEMI COVID-19. Jemasi: Jurnal Ekonomi Manajemen Dan Akuntansi, 16(2), 1-16.

Asbari, Masduki, Pramono, R., Kotamena, F., Liem, J., Sihite, O. B., Alamsyah, V. U., Imelda, D., Setiawan, S. T., \& Agus Purwanto. (2020). Studi Fenomenologi Work-Family Conflict Dalam Kehidupan Guru Honorer Wanita. Edumaspul - Jurnal Pendidikan, 4(1), 180-201. https://doi.org/https://doi.org/10.33487/edumaspul.v4i1.347

Asbari, Masduki, Prasetya, A. B., Santoso, P. B., \& Purwanto, A. (2021). From Creativity to Innovation: The Role of Female Employees' Psychological Capital. International Journal of Social and $\begin{array}{llll}\text { Management Studies } & \text { (IJOSMAS), 62(02), }\end{array}$ https:/ijosmas.org/index.php/ijosmas/article/view/18

Asbari, Masduki, Purba, J. T., Hariandja, E. S., \& Sudibjo, N. (2021). From Leadership to Innovation: Managing Employee Creativity. Jurnal Manajemen Strategi Dan Aplikasi Bisnis, 4(1), 143-154.

Asbari, Masduki, Purwanto, A., Ong, F., Mustikasiwi, A., Maesaroh, S., Mustofa, Hutagalung, D., \& Andriyani, Y. (2020). Impact of Hard Skills, Soft Skills and Organizational Culture: Lecturer Innovation Competencies as Mediating. EduPsyCouns: Journal of Education, Psychology and Counseling, 2(1), 101-121.

Asbari, Masduki, Santoso, P. B., \& Prasetya, A. B. (2020). Elitical and Antidemocratic Transformational Leadership Critics: Is It Still Relevant? (A Literature Study). International Journal of Sociology, Policy and Law (Ijospl), 01(01), 11-16. https://doi.org/https://doi.org/10.8888/ijospl.v1i1.10

Asbari, Masduki, Wijayanti, L. M., Hyun, C. C., Purwanto, A., \& Santoso, P. B. (2019). Effect of Tacit and Explicit Knowledge Sharing on Teacher Innovation Capability. Dinamika Pendidikan, 14(2), 227-243.

Avby, G., \& Kjellström, S. (2019). LearnOvation: an intervention to foster exploration and exploitation behaviour in health care management in daily practice. BMC Health Services Research, 19(1), 19.

Basuki, S., Novitasari, D., Fahlevi, M., Nadeak, M., Fahmi, K., Pebrina, E. T., Sudiyono, R. N., \& Asbari, M. (2020). Performance Analysis of Female Employees in the Covid-19 Pandemic Period: The Effects of Readiness for Change and Effectiveness of Transformational Leadership. Solid State Technology, 63(1s), 201-217. http://www.solidstatetechnology.us/index.php/JSST/article/view/709

Battistelli, A., Montani, F., \& Odoardi, C. (2013). The impact of feedback from job and task autonomy in the relationship between dispositional resistance to change and innovative work behaviour. European Journal of Work and Organizational Psychology, 22(1), 26-41. 
Chang, L.-C., \& Liu, C.-H. (2008). Employee empowerment, innovative behavior and job productivity of public health nurses: A cross-sectional questionnaire survey. International Journal of Nursing Studies, 45(10), 1442-1448.

Chin, W. (1998). The Partial Least Squares Approach to Structural Equation Modeling (E. Modern Methods for Business Research, In: G. A. Marcoulides (ed.)). Lawrence Erlbaum Associates Publisher.

Choi, J. (2020). The mediating effect of positive psychological capital between autonomous work environment and self-directed behavior: evidence from South Korea. Human Resource Development International, 23(1), 46-65.

Fayzhall, M., Purwanto, A., Asbari, M., Basuki, S., Mustofa, M., Hutagalung, D., Maesaroh, S., Winanti, W., Chidir, G., \& Goestjahjanti, F. S. (2020). Pengaruh Gaya Kepemimpinan Terhadap Kapabilitas Inovasi Guru Dalam Perspektif Organizational Learning. EduPsyCouns: Journal of Education, Psychology and Counseling, 2(1), 64-91.

Fikri, M. A. A., Asbari, M., Purwanto, A., Nugroho, Y. A., Waruwu, H., Fauji, A., Shobihi, A. W., Singgih, E., Sudiyono, R. N., Agistiawati, E., \& Dewi, W. R. (2020). A Mediation Role of Organizational Learning on Relationship of Hard Skills, Soft Skills, Innovation and Performance: Evidence at Islamic School. EduPsyCouns: Journal of Education, Psychology and Counseling, 2(1), 398-423. https://ummaspul.e-journal.id/Edupsycouns/article/view/498

Fornell, C., \& Larcker, D. F. (1981). Evaluating Structural Equation Models with Unobservable Variables and Measurement Error. Journal of Marketing Research, 18(1), 39. https://doi.org/10.2307/3151312

Fritsch, M. (2017). The theory of economic development-An inquiry into profits, capital, credit, interest, and the business cycle. Regional Studies, 51(4), 654-655.

Fuglsang, L. (2010). Bricolage and invisible innovation in public service innovation. Journal of Innovation Economics Management, 1, 67-87.

Gagné, M., \& Deci, E. L. (2005). Self-determination theory and work motivation. Journal of Organizational Behavior, 26(4), 331-362.

Gallouj, F., \& Weinstein, O. (1997). Innovation in services. Research Policy, 26(4-5), 537-556.

Ghozali, I. (2014). Structural Equation Modeling, Metode Alternatif dengan Partial Least Square (PLS) (4th ed.). Badan Penerbit Universitas Diponegoro.

Goestjahjanti, S. F., Novitasari, D., Hutagalung, D., Asbari, M., \& Supono, J. (2020). Impact of Talent Management, Authentic Leadership and Employee Engagement on Job Satisfaction: Evidence From South East Asian Industries. Journal of Critical Reviews, 7(19), 67-88. http://www.jcreview.com/?mno=101983

Hair, J. F., Black, W. C., Babin, B. J., \& Anderson, R. E. (2010). Multivariate Data Analysis (7th ed.). Pearson Prentice Hall.

Hocine, Z., \& Zhang, J. (2014). Autonomy support: Explaining the path from leadership to employee creative performance. Open Journal of Social Sciences, 2014.

Hult, G. T. M., Hurley, R. F., \& Knight, G. A. (2004). Innovativeness: Its antecedents and impact on business performance. Industrial Marketing Management, 33(5), 429-438.

Hutagalung, D., Admiral, Nuryanti, Y., Asbari, M., \& Novitasari, D. (2021). Managing Tacit Knowledge Sharing: From Charismatic Leadership to Psychological Safety Climate. Inovbiz: Jurnal Inovasi Bisnis, 9(1), 108-119. https://doi.org/10.35314/inovbiz.v9i1.1888

Hutagalung, D., Asbari, M., Fayzhall, M., Ariyanto, E., Agistiawati, E., Sudiyono, R. N., Waruwu, H., Goestjahjanti, F. S., Winanti, \& Yuwono, T. (2020). Peran Religiusitas, Kepemimpinan Transformasional, Kepuasan Kerja dan Mediasi Organizational Citizenship Behavior terhadap Kinerja Guru. EduPsyCouns: Journal of Education, Psychology and Counseling, 2(1), 311-326. https://ummaspul.e-journal.id/Edupsycouns/article/view/483 
Hutagalung, D., Sopa, A., Asbari, M., Cahyono, Y., Maesaroh, S., \& Chidir, G. (2020). Influence of Soft Skills, Hard Skills and Organization Learning on Teachers' Performance through Innovation Capability as Mediator. Journal of Critical Reviews, 7(19), 54-66. http://www.jcreview.com/?mno=101978

Hyun, C. C., Wijayanti, L. M., Asbari, M., Purwanto, A., Santoso, P. B., Igak, W., Bernarto, I., \& Pramono, R. (2020). Implementation of contextual teaching and learning (CTL) to improve the concept and practice of love for faith-learning integration. International Journal of Control and Automation, 13(1), 365-383.

Janssen, O. (2000). Job demands, perceptions of effort-reward fairness nd innovative work behavior. Journal of Occupational and Organizational Psychology, 73, 287-302.

Johan, M., Budiadnyana, G. N., Admiral, Asbari, M., \& Novitasari, D. (2021). Kepemimpinan Karismatik dalam Perspektif Karyawan UMKM: dari Motivasi Intrinsik hingga Tacit Knowledge Sharing. Edumaspul: Jurnal Pendidikan, 5(1), 598-613. https://ummaspul.ejournal.id/maspuljr/article/view/1303

Jumiran, Novitasari, D., Nugroho, Y. A., Sutardi, D., Sasono, I., \& Asbari, M. (2020). Pengaruh Dimensi Kepemimpinan Transformasional terhadap Kepuasan Kerja dan Komitmen Organisasional: Studi Kasus pada Dosen Perguruan Tinggi Swasta. EduPsyCouns: Journal of Education, Psychology and Counseling, 2(1), 600-621. https://ummaspul.e-journal.id/Edupsycouns/article/view/555

Kamar, K., Novitasari, D., Asbari, M., Winanti, W., \& Goestjahjanti, F. S. (2020). Enhancing Employee Performance During the Covid-19 Pandemic: the Role of Readiness for Change Mentality. JDM (Jurnal Dinamika Manajemen), 11(2), 154-166.

Kanat-Maymon, Y., \& Reizer, A. (2017). Supervisors' autonomy support as a predictor of job performance trajectories. Applied Psychology, 66(3), 468-486.

Kim, S.-J., \& Park, M. (2015). Leadership, knowledge sharing, and creativity: The key factors in nurses' innovative behaviors. JONA: The Journal of Nursing Administration, 45(12), 615-621.

Knol, J., \& Van Linge, R. (2009). Innovative behaviour: The effect of structural and psychological empowerment on nurses. Journal of Advanced Nursing, 65(2), 359-370.

Lai, K., Nathan, R., Tan, K., \& Chan, B. (2010). Effect of Innovation to the Success of Female Entrepreneurs. Journal of Innovation Management in Small and Medium Enterprise, 2010, 1-14. https://doi.org/10.5171/2010.369877

Luthans, F., Avolio, B. J., Avey, J. B., \& Norman, S. M. (2007a). Positive psychological capital: Measurement and relationship with performance and satisfaction. Personnel Psychology, 60(3), 541-572.

Luthans, F., Avolio, B. J., Avey, J. B., \& Norman, S. M. (2007b). Positive psychological capital: Measurement and relationship with performance and satisfaction. Personnel Psychology, 60(3), 541-572. https://doi.org/10.1111/j.1744-6570.2007.00083.x

Luthans, F., \& Youssef-Morgan, C. M. (2017). Psychological Capital: An Evidence-Based Positive Approach. Annual Review of Organizational Psychology and Organizational Behavior, 4, 339366. https://doi.org/10.1146/annurev-orgpsych-032516-113324

Maesaroh, S., Asbari, M., Hutagalung, D., Agistiawati, E., Basuki, S., Radita, F. R., Nurasiah, Yulia, Y., Singgih, E., \& Chidir, G. (2020). Pengaruh Religiusitas dan Kepemimpinan Transformasional terhadap Kinerja Guru melalui Mediasi Organizational Citizenship Behavior. EduPsyCouns: Journal of Education, Psychology and Counseling, 2(1), 276-290. https://ummaspul.ejournal.id/Edupsycouns/article/view/473

Novitasari, D., \& Asbari, M. (2020a). Pengaruh Kepemimpinan Transformasional terhadap Kinerja Karyawan: Peran Kesiapan untuk Berubah sebagai Mediator. Jurnal Manajemen, 10(2), 84-99. https://e-jurnal.lppmunsera.org/index.php/JM/article/view/2371

Novitasari, D., \& Asbari, M. (2020b). Peran Kesiapan untuk Berubah terhadap Kinerja Guru di Masa Pandemi Covid-19. Journal of Industrial Engineering \& Management Research (JIEMAR), 1(2), 219-237. https://jiemar.org/index.php/jiemar/article/view/63 
Novitasari, D., \& Asbari, M. (2020c). Urgensi Kepemimpinan dan Mentalitas Siap Berubah terhadap Kinerja Pegawai di Masa Pandemi Covid-19. Jurnal REKOMEN (Riset Ekonomi Manajemen), 4(1), 66-80. https:/jurnal.untidar.ac.id/index.php/rekomen/article/view/2712

Novitasari, D., \& Asbari, M. (2021). Leaders Coaching di Sekolah: Apa Perannya terhadap Kinerja Guru? Edumaspul: Jurnal Pendidikan, 5(1), 580-597. https://ummaspul.ejournal.id/maspuljr/article/view/1299

Novitasari, D., Asbari, M., Hutagalung, D., \& Amri, L. H. A. (2021). Mengelola Komitmen Dosen: Analisis Peran Modal Psikologis dan Leaders Coaching. Value: Jurnal Manajemen Dan Akuntansi, 16(1), 198-213. https://e-journal.umc.ac.id/index.php/VL/article/view/1845

Novitasari, D., Goestjahjanti, F. S., \& Asbari, M. (2020). The Role of Readiness to Change between Transformational Leadership and Performance: Evidence from a Hospital during Covid-19 Pandemic. APMBA (Asia Pacific Management and Business Application), 9(1), 37-56. https://doi.org/10.21776/ub.apmba.2020.009.01.4

Novitasari, D., Haque, M. G., Supriatna, H., Asbari, M., \& Purwanto, A. (2021). Understanding the Links between Charismatic Leadership, Intrinsic Motivation and Tacit Knowledge Sharing among MSME Employees. International Journal of Social and Management Studies (IJOSMAS), 02(03), 1-13. https://www.ijosmas.org/index.php/ijosmas/article/view/29

Novitasari, D., Kumoro, D. F. C., Yuwono, T., \& Asbari, M. (2020). Authentic Leadership and Innovation: What is the Role of Psychological Capital? International Journal of Science and Management Studies (IJSMS), 3(5), 27-42. https://www.ijsmsjournal.org/volume3-issue5.html

Novitasari, D., Sasono, I., Santoso, J., Sudiyono, R. N., \& Asbari, M. (2020). Pengaruh Kesiapan untuk Berubah pada Karyawan Manufaktur: Analisis Praktik Kepemimpinan di Masa Pandemi Covid19. JUMBO (Jurnal Manajemen , Bisnis Dan Organisasi ), 4(1), 175-188. https://doi.org/http://dx.doi.org/10.33772/jumbo.v4i1.13260

Novitasari, D., Supriatna, H., Asbari, M., Nugroho, Y. A., \& Nadeak, M. (2021). Exploring the Impact of Trust in Leader and Knowledge Sharing on Employee Innovation. International Journal of Social and Management Studies (IJOSMAS), 02(03), 47-62. https://www.ijosmas.org/index.php/ijosmas/article/view/30

Novitasari, D., Yuwono, T., Cahyono, Y., Asbari, M., \& Sajudin, M. (2020). Effect of Hard Skills, Soft Skills, Organizational Learning and Innovation Capability on Indonesian Teachers' Performance during Covid-19 Pandemic. Solid State Technology, 63(6), 2927-2952. http://www.solidstatetechnology.us/index.php/JSST/article/view/3379

Nugroho, Y. A., Asbari, M., Purwanto, A., Basuki, S., Sudiyono, R. N., Fikri, M. A. A., Hulu, P., Mustofa, Chidir, G., \& Suroso. (2020). Transformational Leadership and Employees' Performance: the Mediating Role of Motivation and Work Environment. EduPsyCouns: Journal of Education, Psychology and Counseling, 2(1), 438-460.

Nuryanti, Y., Novitasari, D., Nugroho, Y. A., Fauji, A., Gazali, \& Asbari, M. (2020). Meningkatkan Komitmen Organisasional Dosen: Analisis Pengaruh Kepemimpinan Perguruan Tinggi dan Kepuasan Intrinsik \& Ekstrinsik Dosen. EduPsyCouns: Journal of Education, Psychology and Counseling, 2(1), 561-581.

Ong, F., Purwanto, A., Supono, J., Hasna, S., Novitasari, D., \& Asbari, M. (2020). Does Quality Management System ISO 9001:2015 Influence Company Performance? Answers from Indonesian Tourism Industries. Test Engineering and Management, 83, 24808-24817. http://www.testmagzine.biz/index.php/testmagzine/article/view/12202

Purwanto, A., Asbari, M., Budi Santoso, P., Mayesti Wijayanti, L., Chi Hyun, C., Berman Sihite, O., \& Prameswari Saifuddin, M. (2020). Pengaruh Gaya Kepemimpinan Partisipatif dan Otokratis Terhadap Kinerja Sistem Jaminan Halal HAS 23000 Pada Industri Makanan Kemasan. Edumaspul - Jurnal Pendidikan, 4(1). https://www.researchgate.net/publication/339470652_Pengaruh_Gaya_Kepemimpinan_Partisipa tif_dan_Otokratis_Terhadap_Kinerja_Sistem_Jaminan_Halal_HAS_23000_Pada_Industri_Maka nan_Kemasan 
PURWANTO, A., Asbari, M., Budi Santoso, P. W., \& LM, H. (n.d.). CC (2020). ISO 38200: 2018 Benefit and Timber Industries Competitiveness: Rethoric or Reality. JEMA: Journal of Economic, Management and Accounting Adpertisi, 1 (1).

Purwanto, A., Asbari, M., \& Hadi, A. H. (2020). Pengaruh Gaya Kepemimpinan Tansformational, Authentic, Authoritarian, Transactional Terhadap Kinerja Guru Pesantren di Tangerang. Dirasah, 3(1). https://ejournal.iaifa.ac.id/index.php/dirasah

Purwanto, A., Asbari, M., Hartuti, Setiana, Y. N., \& Fahmi, K. (2021). Effect of Psychological Capital and Authentic Leadership on Innovation Work Behavior. International Journal of Social and $\begin{array}{llll}\text { Management Studies } & \text { (IJOSMAS), }\end{array}$ https://ijosmas.org/index.php/ijosmas/article/view/4

Purwanto, A., Asbari, M., Prameswari, M., Ramdan, M., \& Setiawan, S. (2020). Dampak Kepemimpinan, Budaya Organisasi dan Perilaku Kerja Inovatif Terhadap Kinerja Pegawai Puskesmas. Jurnal Ilmu Kesehatan Masyarakat, 9(01), 19-27.

Purwanto, A., Budi Santoso, P., \& Asbari, M. (2020). Effect Of Integrated ManagementaSystem Of ISO 9001:2015 And Iso 22000:2018 Implementation To Packaging Industries Quality Performance In Banten. Jurnal Ilmiah MEA (Manajemen, Ekonomi, Dan Akuntansi), 4(1), 17-29. https://doi.org/https://doi.org/10.31955/mea.vol4.iss1.pp17-31

Purwanto, A., Pramono, R., Asbari, M., Senjaya, P., Hadi, A. H., Andriyani, Y., \& 李枫. (2020). Pengaruh Kepemimpinan terhadap Kinerja Guru Sekolah Dasar dengan Keterlibatan Kerja dan Budaya Organisasi sebagai Mediator. EduPsyCouns: Journal of Education, Psychology and Counseling, 2(1), 50-63.

Saleem, M., Tufail, M. W., Atta, A., \& Asghar, S. (2015). Innovative workplace behavior, motivation level, and perceived stress among healthcare employees. Pakistan Journal of Commerce and Social Sciences (PJCSS), 9(2), 438-446.

Santoso, P., Purwanto, A., \& Asbari, M. (2019). Influence of Implementation Chain of Custody Forest Management System FSC-STD-40-004 V3-0 to Business Performance of Paper Industriesia in Banten Indonesia. International Journal of Management and Humanities (IJMH), 4(4), 32-36.

Schumpeter, J. A. (2008). The theory of economic development.

Scott, S., \& Bruce, R. (1994). Determinants of innovative behavior: a path model of individual innovation in the workplace. Academy of Management Journal, 37(3), 580-607. https://doi.org/10.1049/iet-rsn:20080009

Sekaran, U., \& Bougie, R. (2003). Research Methods For Business: A Skill Building Approach (Sixth edit). John Wiley and Sons, Inc.

Silitonga, N., Johan, M., Asbari, M., Hutagalung, D., \& Novitasari, D. (2021). Mengelola Kinerja Tim Engineering: Dari Iklim Kecerdasan Emosional hingga Team Efficacy. Value : Jurnal Manajemen Dan Akuntansi, 16(1), 172-187. https://e-journal.umc.ac.id/index.php/VL/article/view/1839

Silitonga, N., Novitasari, D., Sutardi, D., Sopa, A., Asbari, M., Yulia, Y., Supono, J., \& Fauji, A. (2020). The Relationship of Transformational Leadership, Organizational Justice and Organizational Commitment: a Mediation Effect of Job Satisfaction. Journal of Critical Reviews, 7(19), 89-108. http://www.jcreview.com/?mno=101999

Slåtten, T., Mutonyi, B. R., \& Lien, G. (2020). The impact of individual creativity, psychological capital, and leadership autonomy support on hospital employees' innovative behaviour. BMC Health Services Research, 20(1096), 1-17. https://doi.org/https://doi.org/10.1186/s12913-020-05954-4

Slåtten, Terje, Lien, G., Horn, C. M. F., \& Pedersen, E. (2019). The links between psychological capital, social capital, and work-related performance-A study of service sales representatives. Total Quality Management \& Business Excellence, 30(sup1), S195-S209.

Sudiyono, R. N., Goestjahjanti, F. S., Asbari, M., Fayzhall, M., Yani, A., Winanti, Yuwono, T., Nurasiah, Yulia, Y., Singgih, E., \& Chidir, G. (2020). Meningkatkan Komitmen dan Kinerja Dosen : Apa Peran Manajemen Perguruan Tinggi? EduPsyCouns: Journal of Education, Psychology and Counseling, 2(1), 337-352. https://ummaspul.e-journal.id/Edupsycouns/article/view/489/283 
Sugiyono, P. D. (2017). Metode Penelitian Bisnis: Pendekatan Kuantitatif, Kualitatif, Kombinasi, dan R\&D. Penerbit CV. Alfabeta: Bandung.

Suprapti, Asbari, M., Cahyono, Y., \& Mufid, A. (2020). Leadership Style, Organizational Culture and Innovative Behavior on Public Health Center Performance During Pandemic Covid-19. Journal of Industrial Engineering \& Management Research, 1(2). https://doi.org/https://doi.org/10.7777/jiemar.v1i2

Sutardi, D., Novitasari, D., Asbari, M., Silitonga, N., Nugroho, Y. A., Hutagalung, D., Mustofa, Chidir, G., Basuki, S., \& Yuwono, T. (2020). Pengaruh Work-Family Conflict, Stres Kerja dan Social Support terhadap Kepuasan Kerja: Studi Kasus pada Guru Wanita di Tangerang. EduPsyCouns: Journal of Education, Psychology and Counseling, 2(1), 482-498. https://ummaspul.ejournal.id/Edupsycouns/article/view/513

Toivonen, M., Tuominen, T., \& Brax, S. (2007). Innovation process interlinked with the process of service delivery: a management challenge in KIBS. Economies et Sociétés, 41(3), 355.

Yu, X., Li, D., Tsai, C.-H., \& Wang, C. (2019). The role of psychological capital in employee creativity. Career Development International.

Yuwono, T., Novitasari, D., Asbari, M., Sutardi, D., Mustofa, \& Asbari, M. (2020). Peran Organizational Commitment terhadap Hubungan Work- Family Conflict dan Kepuasan Kerja Karyawan Wanita di Kota Seribu Industri Tangerang. EduPsyCouns: Journal of Education, Psychology and Counseling, 2(1), 524-540. https://ummaspul.e-journal.id/Edupsycouns/article/view/526/303

Yuwono, T., Wiyono, N., Asbari, M., Novitasari, D., \& Silitonga, N. (2020). Analisis Pengaruh Efektivitas Kepemimpinan Transformasional dan Kesiapan untuk Berubah terhadap Kinerja Karyawan Wanita di Masa Pandemi Covid-19. Jurnal Ilmiah Mahasiswa Ekonomi Manajemen, 5(3), 615-632. http://www.jim.unsyiah.ac.id/EKM/article/view/15502

Zaman, M. N., Novitasari, D., Goestjahjanti, F. S., Fahlevi, M., Nadeak, M., Fahmi, K., Setiawan, T., \& Asbari, M. (2020). Effect of Readiness to Change and Effectiveness of Transformational Leadership on Workers 'Performance during Covid-19 Pandemic. Solid State Technology, 63(1s), 185-200. http://www.solidstatetechnology.us/index.php/JSST/article/view/708 